REVIEW ARTICLE

\title{
Microsporidian xenomas in fish seen in wider perspective
}

\author{
Jiří Lom ${ }^{1}$ and Iva Dyková ${ }^{1,2}$ \\ ${ }^{1}$ Institute of Parasitology, Academy of Sciences of the Czech Republic, Branišovská 31, 37005 České Budějovice, Czech \\ Republic; \\ ${ }^{2}$ Faculty of Biological Sciences, University of South Bohemia, Branišovská 31, 37005 České Budějovice, Czech Republic
}

Key words: fish microsporidia, xenoma, life cycles, cell pathology

\begin{abstract}
The history of understanding xenoparasitic complexes or xenomas provoked in the host cell by various protists and especially by microsporidia is outlined. Microsporidia have been known to produce xenomas in oligochaetes (e.g., genera Bacillidium, Burkea, Hrabyeia, Jirovecia, species of the collective group Microsporidium), crustaceans (e.g., Abelspora, Mrazekia), insects (e.g., Polydispyrenia, Thelohania) and poikilothermic vertebrates, mostly fish (Alloglugea, Amazonspora, Glugea, Ichthyosporidium, Loma, Microfilum, Microgemma, Neonosemoides, Pseudoloma, Spraguea, Tetramicra). An overview of characters of xenomas caused by species of these genera is presented. The study of microsporidia causing xenomas in fish offers an insight into cell pathology and is of interest since many of these species are important agents of diseases in commercial fish. Xenomas produced from a few types of target cell display a complete change of organisation of the host cell and differ, according to the agent, in their structure. Recent data show that proliferation of the parasite may have already started in the cells transporting the parasites to the final site of xenoma formation. However, these are preliminary revelations and most of the facets of the life cycle are still to be clarified. Curiously, xenoma-forming microsporidia do not seem to be strictly host specific. The salient features of fish microsporidian xenomas are discussed, such as role of the xenoma, whether its features are host- or microsporidium-dependent, development and demise of the xenoma in the course of time, and host reaction phenomena. The need of further research is emphasised.
\end{abstract}

\section{HISTORICAL INTRODUCTION}

One of the most interesting features of microsporidian biology is the capacity to stimulate hypertrophic growth of the invaded cell of the host animal. A symbiotic co-existence develops between the host cell and its microsporidian parasites and both partners turn into a well-organized xenoparasitic complex. It was Moniez (1887) describing what we know now as Glugea anomala (Moniez, 1887) Gurley, 1983 who clarified the parasitic nature of the Glugea "tumours". Twelve years later, Mrázek (1899) was the first to recognise that infection with what we now term Spraguea lophii (Doflein, 1898) Vávra et Sprague, 1976 turns the ganglion cell of Lophius piscatorius into a huge, cyst-like structure.

Xenoparasitic complex (XC) is actually the term ("complexe xénoparasitaire") used by Chatton (1920), who coined it for the unit involving the parasitic dinoflagellate Sphaeripara catenata and the oikoplast (a huge gland cell) of the appendicularian, Fritillaria pellucida. The host cell undergoes hypertrophy and has many, mostly polyploid, nuclei. The dinoflagellate develops within the cell, forms a thick-walled, disc-shaped hyposome from which long branched rhizoids extend into the host cytoplasm, serving for nutrient absorption. In a later paper, Chatton and Courrier (1923) described a microsporidium now termed Microsporidium cotti
(Chatton et Courrier, 1923) Canning et Lom, 1986, forming XC in the testes of Taurulus bubalis. The hypertrophic host cell residing in a fluid-filled cavity was equipped with a dense microvillous cover.

In Chatton's definition, the XC 1) displays hypertrophy of the host cell provoked by the action of the parasite in the cell, 2) preserves the host cell nucleus and 3) has a cover of absorptive microvilli, which may be missing in some cases.

In 1922, Weissenberg coined the term "xenon" for the XC due to Glugea anomala infecting sticklebacks but later, realising that this term was preoccupied for a chemical element, he changed it to "xenom" or "xenoma" (Weissenberg 1949) and still later redefined the phenomenon (Weissenberg 1968). The term xenoma is now currently used for microsporidian XCs. The xenoma is presently understood as the host cell with a completely changed structure and the parasites proliferating inside it, both components being morphologically and physiologically integrated to form a separate entity with its own development in the host at the expense of which it grows.

This paper was presented at the NATO Advanced Research Workshop "Emergent Pathogens in the 21st Century: First United Workshop on Microsporidia from Invertebrate and Vertebrate Hosts", held in České Budějovice, Czech Republic, July 12-15, 2004.

Address for correspondence: J. Lom, Institute of Parasitology, Academy of Sciences of the Czech Republic, Branišovská 31 , 370 05 České Budějovice, Czech Republic. Phone: ++420 387775 424; Fax: ++420 385310388. 
In fact, hypertrophic growth of host cells and their nuclei due to protistan infection has been observed since about the beginning of the twentieth century. Siedlecki (1901, 1911) observed cell hypertrophy in enterocytes of the tunicate Ciona intestinalis, where it is due to trophonts of the gregarine Lankesteria ascidiae. The hypertrophic cell becomes a mere envelope around the parasite and eventually dies. Hesse (1909) described trophonts of the gregarine Nematocystis magna inducing hypertrophy in seminal cells of earthworms in which it lives; the hypertrophic cell extends as outgrowths into neighbouring cells.

Siedlecki (1902) described meronts of the coccidian Caryotropha mesnili eliciting hypertrophy in spermatogonia of the polychaete Polymnia nebulosa; the affected cell undergoes hypertrophy together with the uninfected neighbours, forming what could be called a syncytial xenoma. Merozoites of several species of the coccidian genus Eimeria, formerly assigned to a separate genus Globidium, induce enormous hypertrophy of infected cells. Thus Eimeria gilruthi produces a xenoma up to $6 \mathrm{~mm}$ in size, with a central nucleus and with a microvillous cover for better nutrient absorption (Chatton 1910). Similarly, E. navillei induces a syncytial xenoma in subepithelial connective tissue cells of the intestine of Natrix viperinus (Guyénot et al. 1922). Merozoites of Aggregata octopiana stimulate hypertrophy of connective tissue cells of intestinal submucosa of octopuses (Wurmbach 1935). A similar species, $A$. eberthi, however, does nothing similar in its cuttlefish host.

In coccidians of the genus Sarcocystis, the invasion of merozoite released from the liver produces in the muscle cell a special type of xenoma, in which the parasite develops inside a peculiar cyst delimiting it from the sarcoplasm proper (e.g., S. cruzi, S. hirsuta, S. arieticanis, S. tenella - see Mehlhorn et al. 1976, Eckert et al. 1992).

A quite different protist, Coelomycidium simulii (Phycomycetes, Chytridiales) developing in adipose cells of simuliid larvae, also produces cell hypertrophy reminiscent of xenoma formation (Weiser 1966). The infected cell and its nucleus increase in volume, then the cell loses its contact with neighbouring cells and is disengaged from the fat body into the haemolymph.

Rather recently, several myxozoans, presently considered to be metazoans, have been found to induce xenoma-like formation in vertebrates, e.g., Myxidium lieberkuehni in renal corpuscles of pike, Esox lucius (Lom et al. 1989), Thelohanellus pyriformis in gill endothelial cells of tench, Tinca tinca (Dyková and Lom 1987), Ortholinea sp. in the kidney of Scatophagus argus (unpublished) and a myxosporean-like parasite in the brain of moles, Talpa europaea (Friedrich et al. 2000). However, in spite of similarity of all these XCs to microsporidian xenomas, there is one essential difference. These XCs harbour cells of just one part of the life cycle of the parasite and the rest takes place elsewhere. In microsporidian xenomas the whole cycle, merogony and sporogony, is confined to the xenoma, apart from the stages developing en route from the portal of entry to the final site of xenoma implantation.

\section{CHANGES ELICITED BY MICROSPORIDIA IN SOME INVERTEBRATE HOST CELLS}

In simple cases of microsporidian infection, the parasite proliferates within the infected cell and the mass of its stages replaces the host cell cytoplasm and distends the cell to various degrees (as e.g., in Nosema apis). Simple hypertrophy of infected insect cells can be exemplified by Microsporidium chaetogastris (Schröder, 1909) Sprague, 1977. This species infects connective and muscle tissue cells of Chaetogaster diaphanus, turning them into hypertrophic multinucleate cells (up to $100 \mu \mathrm{m}$ in size) full of parasites in various stages of development (Schröder 1909). Thelohania tipulae Weissenberg, 1926 causes hypertrophy of infected adipose cells and their nuclei so that eventually, only the nucleus and cell membrane of the infected cell replete with mature spores are left (Weissenberg 1926). Lange and Sokolova (2005) reported formation of xenomas - which they do not specify — from single adipose cells of Locusta migratoria by the microsporidian Johenrea locustae Lange, Becnel et Razafindratiana, 1996.

Special cases are so-called syncytial xenomas caused by microsporidia of the genera Polydispyrenia Canning et Hazard, 1982 and Stempellia Léger et Hesse, 1910 in adipocytes of the fat body of simuliid larvae. These cells undergo hypertrophy, usually including nuclear hypertrophy, fragmentation of nucleoli and appearance of polytenic chromosomes. The whole fat body assumes a syncytial nature and is encased with a PAS-positive basal membrane. Sometimes (in Stempellia) this membrane has a lamellar structure reminiscent of the wall of a Glugea xenoma. It covers syncytial tissue, which arose from dedifferentiated fat body with microsporidian developing stages. The stages are stratified and mature spores concentrate in the middle of the xenoma. At the end of this development, there is a mass of spores in a common cavity enveloped by a basal membrane (Maurand and Manier 1967, Maurand 1973).

Microsporidian xenomas comparable with those of fish occur also in several crustaceans. In Asellus aquaticus, the species Mrazekia argoisi Léger et Hesse, 1916 induces xenomas with a hypertrophic nucleus from fat cells around the stomach (Debaisieux 1931). Microsporidium cyclopis (Vávra, 1962) Sprague, 1977 has no such effect in its copepod host (Vávra 1962). Abelspora portucalensis Azevedo, 1987 infects Carcinus maenas. What was described as a xenoma (Azevedo 1987) is in fact an assemblage of hypertrophic cells each with a large parasitophorous vacuole where the parasites pro liferate. In the parasitic copepod Lepeophtheirus 

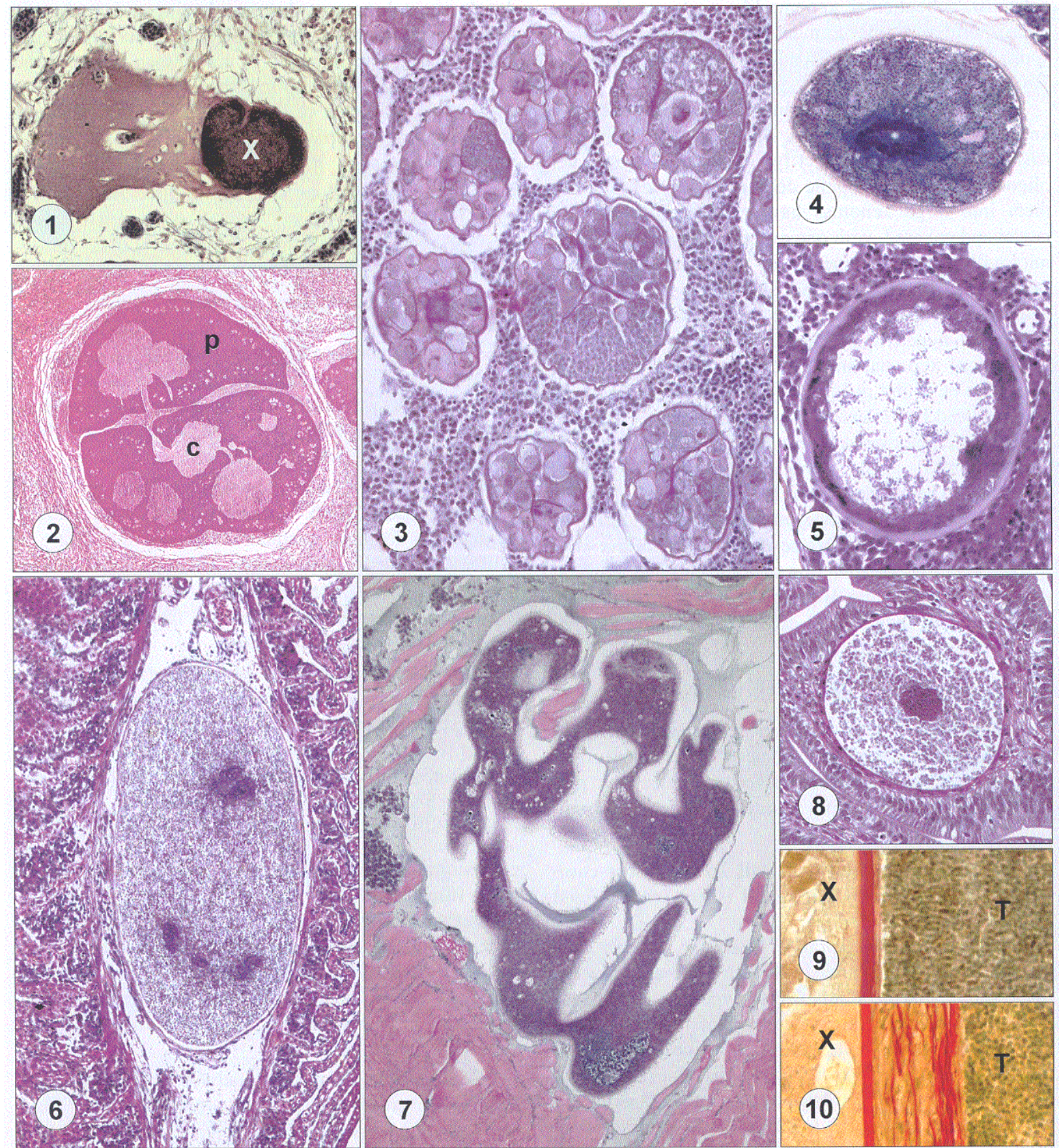

Figs. 1-10. Different types of xenomas of fish microsporidia. Fig. 1. Early stage of Spraguea lophii xenoma; the parasite mass (X) occupies only part of the ganglion cell of Lophius piscatorius. Bodian, $\times 620$. Fig. 2. Advanced stage of S. lophii xenoma in the ganglion of $L$. piscatorius. Note the different staining of parasite mass at the periphery ( $\mathrm{p}$ ) with Nosemoides-type spores and in the centre (c) with Nosema-type spores. H\&E, $\times$ 70. Fig. 3. "Cystic" stages preceding formation of huge xenomas of Ichthyosporidium giganteum. Compartments contain different stages of merogonial proliferation. H\&E, $\times 225$. Fig. 4. Xenoma of Tetramicra brevifilum, in a liquid-filled cavity in liver parenchyma of Scophthalmus maximus. H\&E, $\times 200$. Fig. 5. Mature xenoma of Glugea anomala in the body cavity of Nothobranchius sp. H\&E, $\times 225$. Fig. 6. Xenoma of Loma branchialis in the gills of Melanogrammus aeglefinus. H\&E, $\times 130$. Fig. 7. Xenoma of Tetramicra brevifilum in folded-over shape in the muscle tissue of Scophthalmus maximus. H\&E, $\times 160$. Fig. 8. Loma acerinae xenoma with a centrally located host cell nucleus in the subepithelial connective tissue of the intestine of Gymnocephalus cernuus. H\&E, $\times 260$. Figs. 9, 10. Parts of the wall of similar, mature Glugea plecoglossi xenomas (X), localised in testes $(\mathrm{T})$ of Plecoglossus altivelis. Xenoma wall and mature encircling connective tissue (present in Fig. 10) are stained red. Van Gieson, $\times 1,500$. 
salmonis, subcuticular xenoma-like cysts are due to a microsporidian similar to members of the genus Nucleospora Hedrick, Groff et Baxa, 1991 (see Freeman et al. 2004).

Microsporidian xenomas in oligochaetes have been known since Mrázek (1898). Species of the genus $J i$ rovecia Weiser, 1977 infect lymphocytes of freshwater oligochaetes (chloragogene cells in one case) and turn them into large xenomas having numerous host cell nuclei and covered, with one exception, with densely set microvilli. Similarly, species of the genus Bacillidium Janda, 1928 turn infected lymphocytes (in one case the cells of pharyngeal glands) into large xenomas with one or several hypertrophic nuclei. A review on the fine structure of xenomas in oligochaetes and further references can be found in Larsson (1986). Similar xenomas are produced by Hrabyeia xerkophora Lom et Dyková, 1990 in coelomocytes of Nais christinae (see Lom and Dyková 1990), while Burkea gatesi de Puytorac et Tourret, 1963 was reported to develop xenomas in muscle cells of Pheretima hawayana (de Puytorac and Tourret 1963). There are also several microsporidia with Nosema-like spores, infecting oligochaetes and assigned to the collective group Microsporidium Balbiani, 1884. Some of them induce host cell hypertrophy, some not (Oumouna et al. 2000).

\section{MICROSPORIDIAN XENOMAS IN FISH}

According to the structure of xenomas, genera that comprise xenoma-forming species can be grouped in several categories. (References following the text pertaining to each genus give sources of xenoma description.)

a) Xenomas without a thick wall, in which the complete volume of the original cell is not transformed into xenoma

Spraguea Vávra et Sprague, 1976: the infected zone of a ganglion cell is grossly hypertrophic and covered by a simple plasmalemma. The hypertrophic nucleus (HN) resides in the uninfected part of the cell. In the infected part of the cell, the stages at the periphery of the parasite mass differ (Nosemoides type of spores) from those in the centre (Nosema type) (Figs. 1, 2). Type and only species $S$. lophii in Lophius piscatorius. (Mrázek 1899, Loubès et al. 1979, Takvorian and Cali 1986).

b) Xenomas without a thick wall, with the complete volume of the original cell transformed into xenoma

Ichthyosporidium Caullery et Mesnil, 1905: in the course of the still insufficiently known life cycle of the type species there are two types of xenomas: 1) "cystic" ones, each representing a hypertrophic fibroblast coalescing to form a rounded "syncytial" xenoma (up to only $20 \mu \mathrm{m}$ in size) harbouring immature developmental stages and only rarely producing spores (Fig. 3), and 2) large lobose xenomas (up to $4 \mathrm{~mm}$ ) with intermingled developmental stages and spores, having an ectoplasmic layer covered with a simple plasmalemma and raised into villous projections. It is not known whether the "cystic xenomas" develop into the large xenomas. Type species: I. giganteum in Crenilabrus melops. (Sprague and Vernick 1974, Sprague and Hussey 1980).

Microfilum Faye, Toguebaye et Bouix, 1991: xenomas with a microvillous surface, multiple HNs distributed throughout xenoma, and developmental stages intermingled. Type and only species: M. lutjani in Lutjanus fulgens (Faye et al. 1991).

Microgemma Ralphs et Matthews, 1986: xenomas with plasmalemma raised into surface villosities, reticulate $\mathrm{HN}$ lies between a peripheral band of mitochondria and the cell centre occupied by intermingled stages of the parasite. Type species: M. hepaticus in Chelon labrosus. (Ralphs and Matthews 1986, Amigó et al. 1996, Leiro et al. 1999, Lores et al. 2003).

Microsporidium cotti (Chatton et Courrier, 1923) Canning et Lom, 1986: xenoma invested with a brush border; $\mathrm{HN}$ forms a peripheral net and the centre is filled with intermingled stages. Chatton and Courrier (1923) found it floating in a fluid-filled cavity in the testis of Taurulus bubalis. Warrants further study, may belong to the genus Microgemma.

Tetramicra Matthews et Matthews, 1980: xenoma has microvillous, membrane-bounded projections, by which several xenomas may interlock to form a composite "cyst"; a single reticulate $\mathrm{HN}$, developmental stages intermingled. Type and only species: T. brevifilum in Scophthalmus maximus (Matthews and Matthews 1980) (Figs. 4, 7, 11, 12).

\section{c) Xenomas with plasmalemma covered by host col- lagen fibrils}

Amazonspora Azevedo et Matos, 2003: plasmalemma raised into anastomosing microvilli is covered with up to 22 layers of collagen fibrils; $\mathrm{HN}$ is deeply branched, surrounded by intermingled parasite stages. Type and only species: A. hassar in Hassar orestis (Azevedo and Matos 2003).

Neonosemoides Faye, Toguebaye et Bouix, 1996: xenoma covered with a simple evenly spread plasmalemma covered with a thin glycocalyx, overlaid by host collagen fibrils. Peripheral part is intensively vacuolised, interior containing intermingled stages of the parasite. Type and only species: N. tilapiae in Tilapia zillii (Sakiti and Bouix 1987, Faye et al. 1996).

Nosemoides syacii Faye, Toguebaye et Bouix, 1992: xenoma wall with cell plasma membrane covered with collagen fibres, HN broken into several parts; developmental stages of the parasite are intermingled. In Syacium micrurum (Faye et al. 1994). The generic assignment is most probably wrong, as well as in $N$. zeusi Faye, 1992 and N. brachydeuteri Faye, 1992 (Faye 1992). 

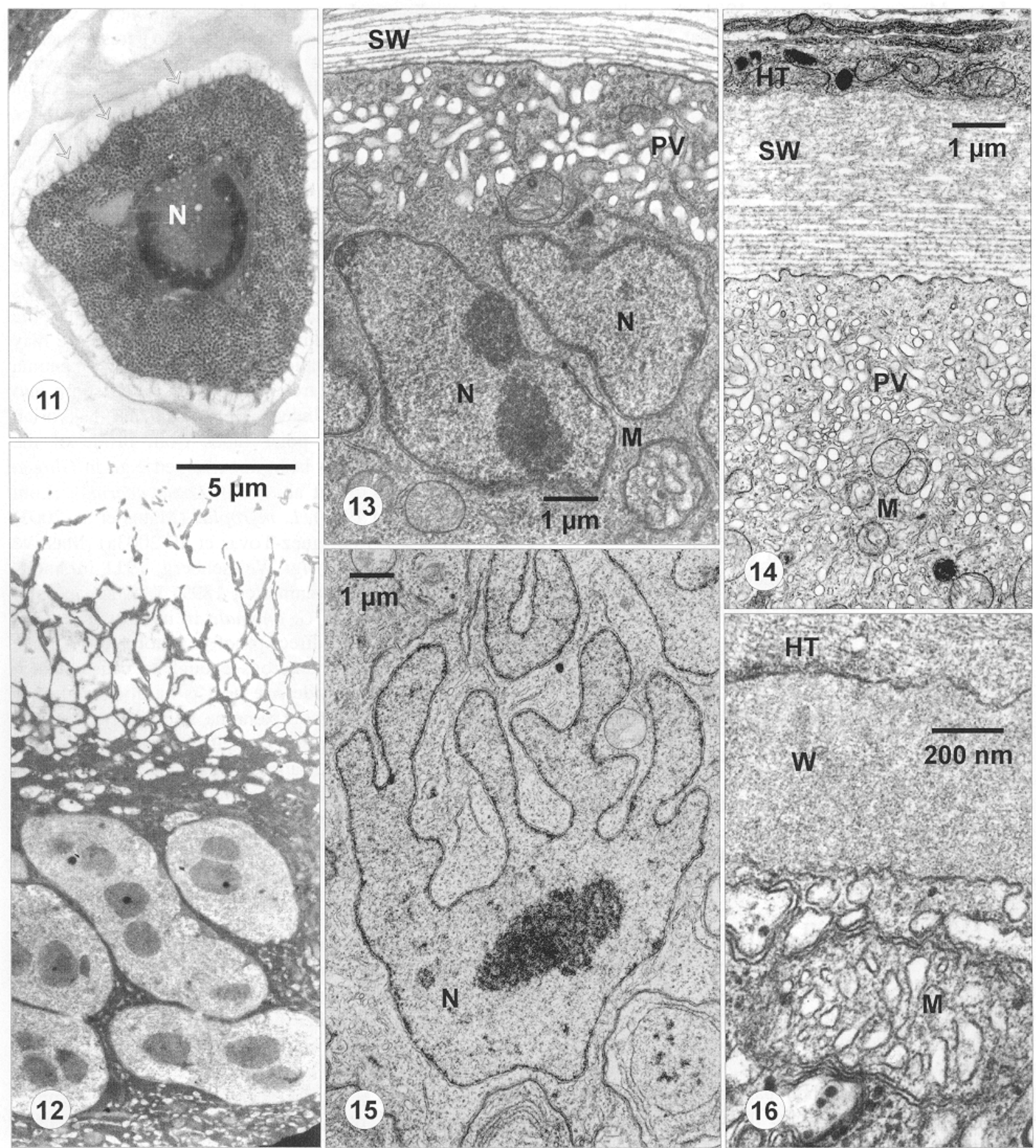

Figs. 11-16. Features of fish xenomas. Fig. 11. Surface villosities (arrows) and centrally located hypertrophic nucleus (N) of Tetramicra brevifilum xenoma. Toluidine blue-stained semithin section, $\times 220$. Fig. 12. Meshwork of surface microvilli of $T$. brevifilum xenoma. Figs. 13, 14. Periphery of an early (Fig. 13) and advanced (Fig. 14) xenoma of Glugea anomala. SW - stratified xenoma wall; PV - pinocytotic vesicles; N - nucleus of the host cell; M - mitochondrion; HT - host tissue. Fig. 15. Branched segment of the hypertrophic nucleus (N) of G. anomala xenoma. Fig. 16. Thick wall (W) of Loma acerinae xenoma. M - mitochondrion; HT - host tissue. Figs. 12-16. Transmission electron micrographs (TEM).

\section{d) Xenomas with a thick wall}

Glugea Thélohan, 1891: laminar layers of sloughedoff cell coat form the wall outside the plasma membrane, the central HN is highly branched, and develop- mental stages are stratified. Type species: G. anomala in Gasterosteus aculeatus. (Weidner 1976, Canning et al. 1982, Takvorian and Cali 1983, Morrison et al. 1985) (Figs. 5, 9, 10, 13-15). 
Loma Morrison et Sprague, 1981: the wall consists of a thick, granular amorphous cell coat, $\mathrm{HN}$ is centrally located, and various developmental stages are intermingled throughout the xenoma. Type species L. branchialis in Melanogrammus aeglefinus. (Morrison and Sprague 1981a, b, 1983, Bekhti 1984, Lom and Pekkarinen 1999) (Figs. 6, 8, 16).

Loma myrophis Azevedo et Matos, 2001: unlike in the type species and perhaps jeopardising the generic assignment, the wall of the xenoma was reported to consist of a layer of fibrous material surrounded by fibroblasts. In Myrophis platyrhynchus (Azevedo and Matos 2002).

Pseudoloma Matthews, Brown, Larison, BishopStewart et Kent, 2001: detailed data on the xenoma are not available.

\section{MICROSPORIDIAN XENOMAS IN VERTEBRATES OTHER THAN FISH}

Alloglugea Paperna et Lainson, 1995: xenomas with a simple folded plasmalemma coated with a layer of host fibroblasts and a central (sometimes fragmented) HN surrounded by stages of the parasite. Type and only species: A. bufonis in tadpoles of Bufo marinus (Paperna and Lainson 1995).

In cultured green monkey kidney (E6) cells infected by the human pathogen Vittaforma corneae (Shadduck, Meccoli, Davis et Font, 1990), a strange type of response of the host cell was described (Leitch et al. 2005), remotely reminding of xenoma organisation. Inhibition of cytokinesis resulted in a cell complex of up to $200 \mu \mathrm{m}$ in size, with a central focus of infection of parasite stages and a single central large microtubuleorganizing centre and peripherally located multiple host cell nuclei.

\section{CHARACTERS OF FISH XENOMAS}

Infection of the host cell involves its complete restructuring. The structure of grown xenomas in fish, compared with the original host cell, in many of them supposedly a leucocyte, is highly varied. The xenomas reveal various surface structures, e.g., microvilli with pinocytotic vesicles at their base and a thick layer of ectoplasm. Inside the xenoma there may be bundles of microfibrils, sometimes annulate membranes, various vesicles or fat globules, modified endoplasmic reticulum, which envelops the developing stages of the parasite, and various tubular structures. The nucleus, always hypertrophic, may be centrally located, branched or lobed, or amitotically divided into a number of fragments sometimes forming a peripheral network. The parasite's capacity to produce xenomas of different structure from a supposedly identical or similar type of host cells seems itself to testify that xenoma structure reflects the nature of the microsporidian and not that of the host.
According to the accepted interpretation, the xenoma offers optimal growth conditions for the parasite including protection against the host immune system, while confining it to one cell and preventing its free spread in the host organism. This is not quite accurate, since spores may discharge their sporoplasms through the xenoma wall and infect the cells that surround it. The newly infected cells may then distribute the infection further in the organism and perpetuate it. Sometimes, "secondary xenomas" may form inside the "primary" one (Fig. 19). It has not been resolved yet whether the secondary xenomas originate in connective tissue cells or macrophages that have broken through the wall of the old xenoma. The stimulus for polar tube discharge may be increased hydrostatic pressure inside the xenoma and/or catabolism of trehalose stored in the spore into smaller molecules (Undeen 1990, Cali and Takvorian 1999). Discharge of polar tubes from inside of the xenoma (Fig. 21) has been documented e.g., in Glugea capverdensis (Lom et al. 1980), Loma acerinae (Lom and Pekkarinen 1999), L. myrophis (Matos et al. 2003) and Loma sp. (Rodríguez-Tovar et al. 2003a). Massive infections of $G$. hertwigi Weissenberg, 1911 in smelts and G. stephani (Hagenmüller, 1899) Woodcock, 1904 in flatfish or even of $G$. anomala in its hosts (Fig. 32) can be used as an indirect proof of autoinfection since ingestion of spores numerous enough to cause such a mass of xenomas inside one host is hardly imaginable and ingestion of a whole xenoma is unlikely. Xenoma only protects the parasite when it is young or growing. As soon as the wall of a grown xenoma has lost its integrity, it is pervaded by granulation tissue and the spores are digested by macrophages (Fig. 20) (Dyková and Lom 1980, Leiro et al. 1999). The spores may also be set free by rupture of xenomas located on the body surface or by decay of the perished host.

There is a long-standing question, whether the xenoma formation and its nature depend on the innate qualities of the parasite or of the host. Thus far no xenoma-forming microsporidian is available in culture to show in vitro whether the microsporidian could transform into a xenoma when the cell is relieved from the influence of the host organism. This would decide the question. Lores et al. (2003) cultured a xenoma-forming microsporidian of uncertain identity (Glugea?) in a mosquito cell line. They observed hypertrophy of nucleus and cytoplasm but no true xenoma formation. Insect cells might not be the proper environments for a fish xenoma to develop. Even if using well-established fish cell culture, the parasite might not find proper conditions for developing its special capacity for xenoma formation. Pending further experiments, this question can only be approached resorting to comparisons. For examples, there are microsporidia infecting tubificids, which do not elicit xenoma formation unlike species of the genus Jirovecia or Bacillidium, e.g., Microsporidium epithelialis (Oumouna et al. 2000). In addition, 


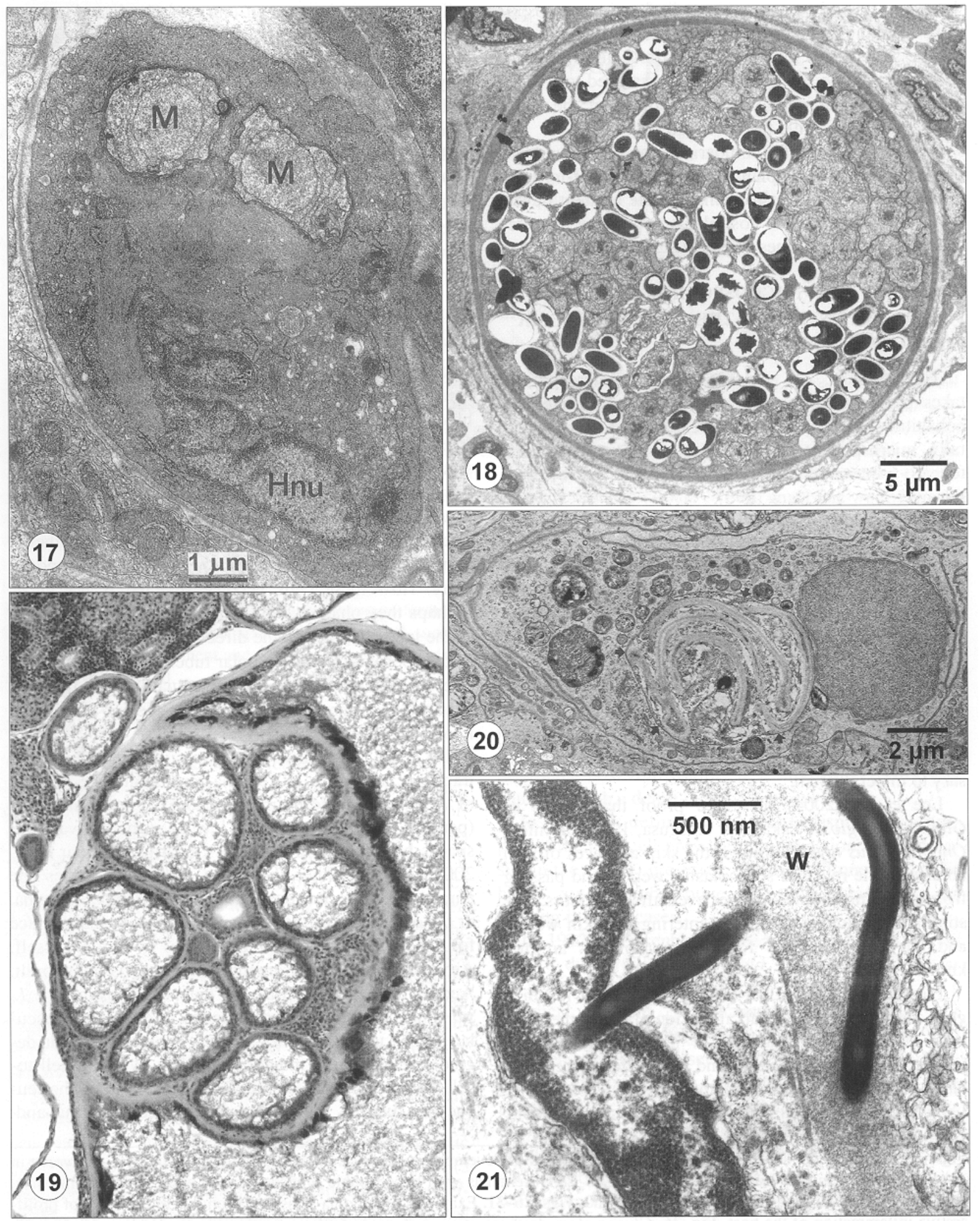

Figs. 17, 18. Growth stages of Loma acerinae xenomas. TEM. Fig. 17. Early stage of development in a slightly transformed neutrophile, day 6 post infection. M - merozoite; Hnu - host cell nucleus. Fig. 18. A grown xenoma with a thick wall and intermingled developmental stages. Host cell nucleus is beyond the level of the section. Fig. 19. A group of secondary Glugea anomala xenomas developing within the old one. H\&E, $\times$ 280. Fig. 20. Chitinous spore shells, the last remnants to be digested from phagocytosed microsporidian spores. TEM. Fig. 21. Discharged polar tubes of Loma acerinae piercing the xenoma wall (W) and (at left) the nucleus of an adjacent fibroblast. TEM. 
there are several xenoma ("cysts")-forming sarcosporidia infecting the same hosts (e.g., sheep, cattle) and yet the structure of their cysts is entirely different from each other. Some Eimeria (formerly assigned to a separate genus "Globidium") elicit xenomas in the same host, e.g., sheep, while the others do not.

A remote but helpful comparison can be drawn from the action of aphids (plant lice) or other gall-forming insects. They are thought to manipulate a latent developmental programme of host plants to produce parasitespecific xenoparasitomes or galls (Stern 1995).

\section{ROUTE OF FISH MICROSPORIDIA FROM THE PORTAL OF ENTRY TO THE SITE OF XENOMA FORMATION}

Transmission of xenoma-forming microsporidia takes place generally per os, which is facilitated by cohabitation of fish with the diseased ones. Experimentally, microsporidia can easily be transmitted intraperitoneally, intramuscularly, intravascularly or by anal gavage (Shaw and Kent 1999).

Glugea spp. are easily transmitted via crustaceans acting as transport hosts. Olson $(1976,1981)$ found that spores of Glugea stephani elicited heavier infections after passage through crustacean digestive tract than when produced by intraperitoneal injection. He even suggested that amphipods might represent a natural route of transmission for G. stephani. Figueras et al. (1992) failed to infect turbots with Tetramicra brevifilum intraperitoneally or by exposure to waterborne spores and concluded that eating aquatic crustaceans - copepods, mysids and decapod larvae- was necessary to infect the fish.

Lee et al. (2004) presented proof that spores of Glugea plecoglossi Takahashi et Egusa, 1977 can infect Oncorhynchus mykiss through the skin at places of skin abrasion. The released sporoplasms were found passing from epidermis to muscle layer even after six hours. The stimuli for hatching of spores entering the skin wound and the transport cells for the sporoplasms are not known.

Pleshinger and Weidner (1985) proved that in Spraguea lophii a shift to the alkaline side of $\mathrm{pH}$ in the presence of polyanions (mucines or polyglutamates) may induce polar tube discharge and hence the spores may hatch in the mucous coat of the intestinal epithelium. Lee et al. (2003) presumed that, after ingestion, mucous cells are the initial sites of entry of $G$. plecoglossi and that pepsin and trypsin may activate hatching in the gastrointestinal tract. Interaction mediated by lectins may be the stimulating factor for this species.

It has been generally assumed that macrophages (Weissenberg 1968) or neutrophils (Bekhti and Bouix 1985, Canning and Lom 1986, Pekkarinen and Lom 1999) are the first sites of infection for Glugea spp. after inoculation of sporoplasms released in the intestine. Their further fate has not been explicitly described. However, merogonial proliferation may presumably start in the cells that were initially infected. Sánchez et al. (2001), using in situ hybridisation technique, have found that Loma salmonae migrates from mucosal epithelium to the lamina propria of the intestine before reaching the final destination in the gills. The dividing merogony stages were then detected within infected blood cells in the heart as early as day 2 post exposure (p.e.), thus proving unequivocally the haematogenous spread by infected blood cells. Transportation and dissemination via blood cells has also been documented for Tetramicra brevifilum (Matthews and Matthews 1980). The transport cells were suggested to be intraepithelial lymphocytes, $\mathrm{T}$ cells or migratory cells such as monocytes. How these cells become infected is not clear. Perhaps they phagocytize the parasite in lamina propria of the intestine, or become directly infected by injection of the sporoplasm via the polar tube. To what extent the infected transport cell may eventually turn into the xenoma in different microsporidian species is still not known.

In Loma salmonae, merogony is initiated in the transport cells prior to xenoma formation. The journey of the already dividing merozoites of L. salmonae ends (perhaps attracted by high $\mathrm{O}_{2}$ levels) in the gill vascular spaces between the pillar cells (Rodríguez-Tovar et al. 2003b). Then, either the pillar cell phagocytizes the parasite from the leucocyte and converts into a xenoma, or the extensions of the pillar cells retract to make space for the leucocyte, which turns into a xenoma itself. Around it, a new basement membrane is then built. Another possibility is that the leucocyte hosting the $L$. salmonae merozoites transmigrates through extravascular spaces using enzymes (metalloproteinases) that degrade the basement membrane and/or by using cell-tocell interaction with endothelial cells. Some of the leucocytes succeed in reaching the connective tissue and

Figs. 22-25. Xenomas of Glugea anomala in early stages of development. Fig. 22. A spontaneous infection of G. anomala in Austrolebias nigripinnis. H\&E, $\times$ 70. Figs. 23-25. Early xenomas with hypertrophic branched nuclei and cylindrical meronts, which predominate in Figs. 24 and 25. H\&E, $\times$ 450. Figs. 26-31. Examples of xenoma transformation due to the onset of proliferative inflammation of the host. Fig. 26. Glugea plecoglossi infection in ovaries of Plecoglossus altivelis. H\&E, × 60. Fig. 27. Proliferation of granulation tissue in Loma acerinae visualised by Masson's trichrome staining, $\times 120$. Fig. 28. Xenoma of Tetramicra brevifilum transformed into granuloma in the liver of Scophthalmus maximus. H\&E, $\times 150$. Fig. 29. Granulomatous lesion at the site of Glugea anomala xenoma in the glandular part of the stomach wall in Gasterosteus aculeatus. H\&E, $\times 220$. Fig. 30. Granuloma in the ovary of Nothobranchius rubripinnis replacing G. anomala xenoma. H\&E, $\times 250$. Fig. 31. Spraguea lophii xenoma partly transformed into a granuloma. H\&E, $\times 220$. Fig. 32. Overview of a massive spontaneous infection of $G$. anomala as seen in the intestine of Gasterosteus aculeatus. H\&E, $\times 70$. 


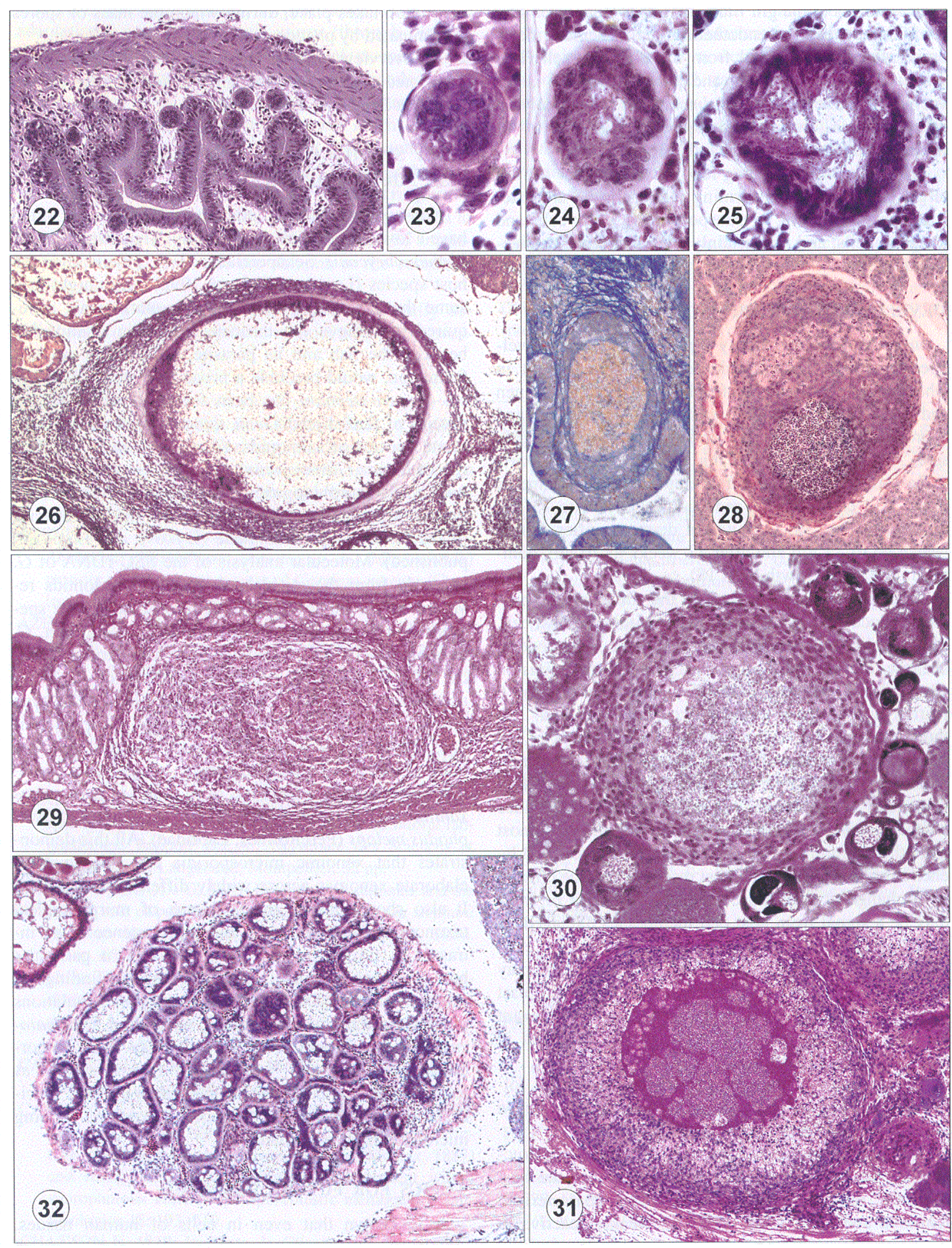


form xenomas in the gill filament. Other leucocytes stay confined between the endothelium and basement membrane after having exited from the blood vessel. How much of tissue specificity and parasite tropism is involved in the case of $L$. salmonae and especially in other xenoma-forming microsporidia has still to be investigated (Rodríguez-Tovar 2003b).

As evident from existing reports, the thus far proven target cells of xenoma-forming microsporidia are macrophages (also acting as transport cells), pillar cells and ganglion cells, and we certainly cannot exclude connective tissue cells.

\section{DEVELOPMENT OF XENOMAS IN FISH}

In Loma acerinae, at day 6 p.e. only meronts enveloped by rough endoplasmic reticulum are present in what was originally the neutrophil (Fig. 17) (Pekkarinen and Lom 1999). Three weeks p.e., merogony and sporogony have progressed and mature spores are present. Xenoma wall, still of thin consistency, only starts to be formed while the cytoskeleton of microfilaments in the host cells is being reduced. By days 6 to 13 , the xenoma reaches up to $8 \mu \mathrm{m}$ in diameter, after 3 to 4 weeks up to $14 \mu \mathrm{m}$ and after 11 weeks to $20 \mu \mathrm{m}$, demonstrating slow growth (Fig. 18).

In Loma salmonae, during the third week p.e., meronts occupied the marginal area within the host cell. This localisation is associated with host mitochondria because of the need of active parasite cell division (Rodríguez-Tovar et al. 2003b) but by weeks 5 and 6 mature spores have already occupied that area. Although on week 5 and 6 p.e. the plasmalemma of the xenoma did not seem injured, the proximity of inflammatory cells indicated that an inflammatory signal of some kind was generated but not so strong as to induce leucocyte attack. Some signals may be emitted almost from the beginning of xenoma formation, as testified by encircling fibroblasts. The host response may be elicited by a change of antigens on the plasmalemma or there may be a signal from host cell membranes damaged by toxic metabolites from the parasite. Nevertheless, even xenomas with integral, undamaged cell membrane may become covered by fibroblasts from the local fibroblast population rearranged due to pressure atrophy. Relevant data on immunogenicity of xenomas can be found in Shaw and Kent (1999).

The progress of xenoma growth can easily be followed in heavy spontaneous infections of Glugea anomala in cyprinodontid hosts (Figs. 22-25).

None of the xenomas, however, escape final destruction by the host (Figs. 26-31). The stages of the host response towards xenoma have been characterized (Dyková and Lom 1978, 1980) as weakly reactive in young and developing xenomas, and productive in fully developed xenomas when proliferative inflammation transforms xenomas in granulomas. Finally, granuloma involution takes place, during which the mass of spores is eliminated by phagocytosis.

An overview of some papers on immune phenomena associated with granuloma growth and demise is presented in Shaw and Kent (1999).

\section{HOST SPECIFICITY OF THE XENOMA-FORMING FISH MICROSPORIDIA}

Non-xenoma-forming microsporidian species often have a low degree of host specificity. Thus Pleistophora hyphessobryconis Schäperclaus, 1941 infects over 18 host species (Lom and Dyková 1992). One might presume that the degree of close co-evolution that is required to achieve the intricate symbiotic relationship between the fish and its parasite, reflected in xenoma formation, would preclude a broad host range. It is not so. Glugea stephani has been found in nine different species of flatfish and Loma salmonae infects nine different species of salmonids. Glugea anomala was first reported in Gasterosteus aculeatus and Pungitius pungitius; morphologically indistinguishable microsporidian populations have been found in eight species of the family Cyprinodontidae (Dyková and Lom, unpublished). Molecular analysis of the SSU rDNA of $G$. anomala from the stickleback and cyprinodontids revealed only a slight degree of difference below the species level (Frank Nilsen, pers. comm.). In addition, $G$. stephani and $G$. atherinae have been found to be identical with G. anomala (Pomport-Castillon et al. 1998) according to SSU rDNA analysis. In addition to the type host Psetta maxima (Pleuronectiformes, Scophthalmidae), Tetramicra brevifilum has been found also in Lophius budegassa (Lophiiformes, Lophiidae). Ichthyosporidium giganteum has been found in Leiostomus xanthurus (Perciformes, Sciaenidae) in addition to Symphodus melops (Perciformes, Labridae). All this demonstrates that xenomic microsporidia are able to form elaborate xenomas across widely different host taxons. It also shows clearly the problems of morphological taxonomy of microsporidia and the existence of an intraspecies polymorphism associated with a particular host. This has been again confirmed by the findings of Freeman et al. (2004) that Spraguea lophii populations in species of the genus Lophius, other than L. piscatorius and L. budegassa, may not display spore dimorphism ("nosema" and "nosemoides" type of spores) as found in the type host. Further studies on the host specificity and intraspecific variation of xenoma-forming microsporidia is warranted.

\section{TOPICS FOR FUTURE RESEARCH}

It is known that even in cells of human tissues, mainly myocard and muscles, there is a plethora of agents, which can induce cell hypertrophy, including various chemicals and products of cells of the organism 
itself. It is also known that cell hypertrophy is one of the adaptational responses to cell injury (through viral or rickettsial infection, physical, chemical or mechanical factors), as an adaptation to heightened demands. These are, however, by no means so elaborate hypertrophies as encountered in microsporidian xenomas. Might there be an inducing factor common to these hypertrophies and to the intricate structures of xenomas? Also, might there be xenoma-inducing agents common in microsporidia infecting various fish and other hosts? Closely related to these questions might be investigation into the immunomodulation potential of the xenoma in the course of its development.

In most of the microsporidian species, a really detailed knowledge of the course of infection is still miss- ing. Precise site of the portal of infection, first-station cells, transport cells, transformation of the original cell cytoskeleton, target cells, exact site of xenoma formation, duration of separate stages of development, way of spreading in the host organism, autoinfection and pathogenicity still await a due scrutiny. Development of in vitro culture techniques for xenoma-inducing microsporidia may help in disclosing relevant characters of xenoma formation.

Acknowledgements. The authors are grateful for financial support received from the research project of the Institute of Parasitology, Academy of Sciences of the Czech Republic (Z60220518) and Ministry of Education, Youth and Sports (project no. MSM 6007665801).

\section{REFERENCES}

AMIGÓ J.M., SALVADÓ H., GRACIA M.P., VIVARÈS C.P. 1996: Ultrastructure and development of Microsporidium ovoideum (Thélohan, 1895) Sprague, 1997, a microsporidian parasite of the red band fish (Cepola macrophthalma L.). Eur. J. Protistol. 32: 532-538.

AZEVEDO C. 1987: Fine structure of the microsporidian Abelspora portucalensis gen. n., sp. n. (Microsporida) parasite of the hepatopancreas of Carcinus maenas (Crustacea, Decapoda). J. Invertebr. Pathol. 49: 83-92.

AZEVEDO D., MATOS E. 2002: Fine structure of a new species, Loma myrophis (Phylum Microsporidia), parasite of the Amazonian fish Myrophis platyrhynchus (Teleostei, Ophichthidae). Eur. J. Protistol. 37: 445-452.

AZEVEDO C., MATOS E. 2003: Amazonspora hassar n. gen. and n. sp. (Phylum Microsporidia, fam. Glugeidae), a parasite of the Amazonian teleost Hassar orestis (fam. Doradidae). J. Parasitol. 89: 336-341.

BEKHTI M. 1984: Étude comparative des espèces des microsporidies parasites des poissons téléostéens du littoral languedocien. Rapport D.E.A., Université des Sciences et Techniques du Languedoc, Montpellier, $32 \mathrm{pp}$.

BEKHTI M., BOUIX G. 1985: Evolution of xenomas and the double role of polynuclear neutrophils in Glugea stephani infection in Platichthys flesus. Ann. Parasitol. Hum. Comp. 60: 509-522.

CALI A., TAKVORIAN P.M. 1999: Developmental morphology and life cycles of the Microsporidia. In: M. Wittner and L.M. Weiss (Eds.), The Microsporidia and Microsporidiosis. ASM Press, Washington, D.C., pp. 85-128.

CANNING E.U., LOM J. 1986: The Microsporidia of Vertebrates. Academic Press, London, 289 pp.

CANNING E.U., LOM J., NICOLAS J.P. 1982: Genus Glugea Thélohan 1891 (Phylum Microspora): redescription of the type species Glugea anomala (Moniez, 1887) and recognition of its sporogonic development within sporophorous vesicles (pansporoblastic membranes). Protistologica 18: 193-210.

CHATTON E. 1910: Le kyste de Gilruth dans la muqueuse stomacale des Ovidés. Arch. Zool. Exp. Gén., 5 (N. et R.): 114-124.
CHATTON E. 1920: Un complexe xéno-parasitaire morphologique et physiologique Neresheimeria paradoxa chez Fritillaria pellucida. C. R. Acad. Sci. Paris 171: 5557.

CHATTON E., COURRIER R. 1923: Formation d'un complexe xénoparasitaire géant avec bordure en brosse, sous l'influence d'une Microsporidie, dans le testicule de Cottus bubalis. C. R. Soc. Biol. (Paris) 89: 579-583.

DEBAISIEUX P. 1931: Études cytologiques du Mrazekia argoisi. Cellule 40: 147-168.

DYKOVÁ I., LOM J. 1978: Tissue reaction of the threespined stickleback Gasterosteus aculeatus L. to infection with Glugea anomala (Moniez, 1887). J. Fish Dis. 1: 8390.

DYKOVÁ I., LOM J. 1980: Tissue reactions to microsporidian infections in fish. J. Fish Dis. 3: 265-283.

DYKOVÁ I., LOM J. 1987: Host cell hypertrophy induced by contact with trophozoites of Thelohanellus pyriformis (Myxozoa: Myxosporea). Arch. Protistenkd. 133: 285293.

ECKERT J., KUTZER E., BÜRGER H.-J., KÖRTING W. 1992: Veterinärmedizinische Parasitologie. Paul Parey, Hamburg, 905 pp.

FAYE N. 1992: Microsporidies des poissons des côtes sénégalaises: faunistique, biologie, ultrastructure. Thesis. Academie de Montpellier, Université Montpellier II, Sciences et Techniques du Languedoc, $241 \mathrm{pp}$.

FAYE N., TOGUEBAYE B.S., BOUIX G. 1991: Microfilum lutjani n. g. n. sp. (Protozoa Microsporida), a gill parasite of the golden African snapper Lutjanus fulgens (Valenciennes, 1830) (Teleost Lutjanidae): developmental cycle and ultrastructure. J. Protozool. 38: 30-40.

FAYE N., TOGUEBAYE B.S., BOUIX G. 1994: Nosemoides syacii $\mathrm{n}$. sp., a microsporidian parasite of the West African turbot Syacium micrurum Ranzani, 1840. Syst. Parasitol. 29: 43-50.

FAYE N., TOGUEBAYE B.S., BOUIX G. 1996: Ultrastructure and development of Neonosemoides tilapiae (Sakiti and Bouix, 1987) n. g., n. comb. (Protozoa, Microspora) from African cichlid fish. Eur. J. Protistol. 32: 320-326. 
FIGUERAS A., NOVOA B., SANTARÉM E., MARTÍNEZ J.M., TORANZO A.E., DYKOVÁ I. 1992: Tetramicra brevifilum, a potential threat to farmed turbot Scophthalmus maximus. Dis. Aquat. Org. 14: 127-135.

FREEMAN M.A., BELL A.S., SOMMERVILLE C. 2003: A hyperparasitic microsporidian infecting the salmon louse, Lepeophtheirus salmonis: an rDNA-based molecular phylogenetic study. J. Fish Dis. 26: 667-676.

FREEMAN M.A., YOKOYAMA H., OGAWA K. 2004: A microsporidian parasite of the genus Spraguea in the nervous tissues of the Japanese anglerfish Lophius litulon. Folia Parasitol. 51: 167-176.

FRIEDRICH C., INGOLIC E., FREITAG B., KASTBERGER G., HOHMANN V., SKOFITSCH G., NEUMEISTER U., KEPKA O. 2000: A myxozoan-like parasite causing xenomas in the brain of the mole, Talpa europaea L., 1758 (Vertebrata, Mammalia). Parasitology 121: 483-492.

GUYÉNOT E., NAVILLE A., POUSE K. 1922: Deux Coccidies parasites de Tropidonotus natrix. Rev. Suisse Zool. 30: 115-157.

HESSE E. 1909: Contribution à l'étude des Monocystidées des Oligochètes. Arch. Zool. Exp. Gén. 43: 27-301.

LANGE C.E., SOKOLOVA Y.Y. 2005: Experimental transmission, pathogen-host relationships, and phenotypic plasticity of Johenrea locustae, a microsporidian pathogen from the migratory locust (Orthoptera: Acrididae). Folia Parasitol. $\mathrm{xxx}-\mathrm{xxx}$.

LARSSON J.I.R. 1986: Ultrastructure, function and classification of microsporidia. In: J.O. Corliss and D.J. Patterson (Eds.), Progress in Protistology, Vol. 1. Biopress, Bristol, pp. 325-390.

LEE S.J., YOKOYAMA H., OGAWA K. 2003: Rapid in situ hybridisation technique for the detection of fish microsporidian parasites. Fish Pathol. 38: 117-119.

LEE S.J., YOKOYAMA H., OGAWA K. 2004: Modes of transmission of Glugea plecoglossi (Microspora) via the skin and digestive tract in an experimental infection model using rainbow trout, Oncorhynchus mykiss (Walbaum). J. Fish Dis. 27: 435-444.

LEIRO J., PARAMÁ A., ORTEGA M., SANTAMARINA M.T., SANMARTÍN M.L. 1999: Redescription of Glugea caulleryi, a microsporidian parasite of the greater sand-eel, Hyperoplus lanceolatus (Le Sauvage) (Teleostei: Ammodytidae), as Microgemma caulleryi comb. nov. J. Fish Dis. 22: $101-110$

LEITCH G.J., SHAW A.P., COLDEN-STANFIELD M., SCANLON M., VISVESVARA G.S. 2005: Multinucleate host cells produced by Vittaforma corneae (Microsporidia). Folia Parasitol. xxx-xxx.

LOM J., DYKOVÁ I. 1990: Hrabyeia xerkophora n. gen. n. sp., a new microsporidian with tailed spores from the oligochaete Nais christinae. Eur. J. Protistol. 25: $243-$ 248.

LOM J., DYKOVÁ I. 1992: Protozoan Parasites of Fishes. Developments in Aquaculture and Fisheries Science 26. Elsevier Science Publishers, Amsterdam-London-New York-Tokyo, $315 \mathrm{pp}$.

LOM J., DYKOVÁ I., FEIST S. 1989: Myxosporea-induced xenoma formation in pike (Esox lucius L.) renal corpus- cles associated with Myxidium lieberkuehni infection. Eur. J. Protistol. 24: 271-280.

LOM J., GAEVSKAYA A.V., DYKOVÁ I. 1980: Two microsporidian parasites found in marine fishes in the Atlantic Ocean. Folia Parasitol. 27: 197-202.

LOM J., PEKKARINEN M. 1999: Ultrastructural observations on Loma acerinae (Jírovec, 1930) comb. n. (Phylum Microsporidia). Acta Protozool. 38: 61-74.

LORES B., ROSLES M.J., MASCARÓ C., OSUNA A. 2003: In vitro culture of Glugea sp. Vet. Parasitol. 112: 185196.

LOUBÈS C., MAURAND J., ORMIÈRES R. 1979: Étude ultrastructurale de Spraguea lophii (Doflein, 1898), Microsporidie parasite de la Baudroie: essai d'interpretation du dimorphisme sporal. Protistologica 15: 43-54.

MATOS E., CORRAL L., AZEVEDO C. 2003: Ultrastructural details of the xenoma of Loma myrophis (phylum Microsporidia) and extrusion of polar tube during autoinfection. Dis. Aquat. Org. 54: 203-207.

MATTHEWS R.A., MATTHEWS B.F. 1980: Cell and tissue reaction of turbot Scophthalmus maximus (L.) to Tetramicra brevifilum gen. n., sp. n. (Microspora). J. Fish Dis. 3: 495-515.

MAURAND J. 1973: Recherches Biologiques sur les Microsporidies des Larves de Simulies. Thèse présentée à l'Université des Sciences et Techniques du Languedoc pour obtenir le grade de Docteur ès Sciences (Sciences Naturales). Académie de Montpellier, Université des Sciences et Techniques du Languedoc, $199 \mathrm{pp}$.

MAURAND J., MANIER J.F. 1967: Une Microsporidie nouvelle pour les larves de Simulies. Protistologica 3: 445449.

MEHLHORN H., HARTLEY W.J., HEYDORN A.E. 1976: A comparative ultrastructural study of the cyst wall of 13 Sarcocystis species. Protistologica 12: 451-456.

MONIEZ R. 1887: Observations pour la revision des microsporidies. C. R. Acad. Sci. Paris 104: 1312-1314.

MORRISON C.M., HOFFMAN G.L., SPRAGUE V. 1985: Glugea pimephales (Fantham, 1941) n. comb. (Microsporidia, Glugeidae) in the fathead minnow Pimephales promelas. Can. J. Zool. 63: 380-391.

MORRISON C.M., SPRAGUE V. 1981a: Electron microscope study of a new genus and new species of microsporidia in the gills of Atlantic cod Gadus morhua L. J. Fish Dis. 4: 15-32.

MORRISON C.M., SPRAGUE V. 1981b: Light and electron microscopic study of microsporidia in the gills of haddock, Melanogrammus aeglefinus (L.). J. Fish Dis. 4: 179-184.

MORRISON C.M., SPRAGUE V. 1983: Loma salmonae (Putz, Hoffman and Dunbar, 1965) in the rainbow trout, Salmo gairdneri Richardson, and L. fontinalis sp. nov. (Microsporidia) in the brook trout, Salvelinus fontinalis (Mitchill). J. Fish Dis. 6: 345-353.

MRÁZEK A. 1898: Über eine neue Sporozoenform aus Limnodrilus. Sitzungsber. Böhm. Ges. Wiss. Math.-Naturwiss. Classe (Vol. 1897): 1-5.

MRÁZEK A. 1899: Sporozoenstudien II. Glugea lophii Doflein. Sitzungsber. Böhm. Ges. Wiss. Math.-Naturwiss. Classe: $1-8$ 
OLSON R.E. 1976: Laboratory and field studies on Glugea stephani (Hagenmüller), a microsporidian parasite of pleuronectid flatfishes. J. Protozool. 23: 158-164.

OLSON R.E. 1981: The effect of low temperature on the development of microsporidan Glugea stephani in English sole (Parophrys vetulus). J. Wildl. Dis. 17: 559-562.

OUMOUNA M., El-MATBOULI M., HOFFMANN R.W., BOUIX G. 2000: Electron microscopic study of a new microsporean Microsporidium epithelialis sp. n. infecting Tubifex sp. (Oligochaeta). Folia Parasitol. 47: 257-265.

PAPERNA I., LAINSON R. 1995: Alloglugea bufonis nov. gen., nov. sp. (Microsporea, Glugeidae), a microsporidian of Bufo marinus tadpoles and metamorphosing toads (Amphibia, Anura) from Amazonian Brazil. Dis. Aquat. Org. 23: 7-16.

PEKKARINEN M., LOM J. 1999: Ultrastructure of a microsporidian parasite from oocytes of ruff (Gymnocephalus cernuus) from Finland. Proceedings of the 5th Internat. Symp. on Fish Parasites, 9-13 August 1999, České Budějovice, p. 110.

PLESHINGER J., WEIDNER E. 1985: The microsporidian spore discharge tube IV. Discharge activation begins with pH-triggered $\mathrm{Ca}^{2+}$ influx. J. Cell Biol. 100: 1834-1838.

POMPORT-CASTILLON C., COSTE F., ROMESTAND B., BOUIX G. 1998: The Glugea complex in the Languedocian brackish lagoons: a multidimensional study model of fish Microsporidia. J. Eukaryot. Microbiol. 46: 15A.

PUYTORAC P. de, TOURRET M. 1963: Étude de kystes d'origine parasitaire (microsporidies ou grégarines) sur la paroi interne du corps des vers Megascolecidae. Ann. Parasitol. Hum. Comp. 38: 861-874.

RALPHS J.R., MATTHEWS R.A. 1986: Hepatic microsporidiosis of juvenile grey mullet, Chelon labrosus (Risso), due to Microgemma hepaticus gen. nov. sp. nov. J. Fish Dis. 9: 225-242.

RODRÍGUEZ-TOVAR F.J., WADOWSKA D.W., WRIGHT G.M. 2003a: Ultrastructural evidence of autoinfection in the gills of Atlantic cod Gadus morhua infected with Loma sp. (Phylum Microsporidia). Dis. Aquat. Org. 57: 227-230.

RODRÍGUEZ-TOVAR F.J., WRIGHT G.M., WADOWSKA D.W., SPEARE D.J., MARKHAM R.J.F. 2003b: Ultrastructural study of the late stages of Loma salmonae development in the gills of experimentally infected rainbow trout. J. Parasitol. 89: 464-474.

SAKITI A.G., BOUIX G. 1987: Nosemoides tilapiae n. sp., Microsporidie parasite de Poissons Cichlidae des eaux saumâtres du Bénin: implantation et caractères ultrastructuraux. Parasitol. Res. 73: 203-212.

SÁNCHEZ J.G., SPEARE D.J., MARKHAM R.J.F., WRIGHT G.M., KIBENGE F.S.B. 2001: Localization of the initial developmental stages of Loma salmonae in rainbow trout (Oncorhynchus mykiss). Vet. Pathol. 38: $540-546$.

SCHRÖDER O. 1909: Thelohania chaetogastris, eine neue in Chaetogaster diaphanus Gruith schmarotzende Microsporidienart. Arch. Protistenkd. 14: 119-133.
SHAW R.W., KENT M.L. 1999: Fish Microsporidia. In: M. Wittner and L.M. Weiss (Eds.), The Microsporidia and Microsporidiosis, AMS Press, Washington, D.C., pp. 418 446.

SIEDLECKI M. 1901: Contribution à l'étude des changements cellulaires provoqués par les Grégarines. Arch. Anat. Microsc. 4: 87-100.

SIEDLECKI M. 1902: Cycle évolutif de la Caryotropha mesnili. Bull. Acad. Sci. Cracovie, Série B: 561-568.

SIEDLECKI M. 1911: Veränderungen des Kernplasmarelation während des Wachstums intracellularen Parasiten. Bull. Int. Acad. Sci. Cracovie, Série B, pp. 509-528.

SPRAGUE V., HUSSEY K.L. 1980: Observations of Ichthyosporidium giganteum (Microsporidia) with particular reference to the host-parasite relations during merogony. J. Protozool. 27: 169-175.

SPRAGUE V., VERNICK S.H. 1974: Fine structure of the cyst and some sporulation stages of Ichthyosporidium (Microsporida). J. Protozool. 21: 667-677.

STERN D.L. 1995: Phylogenetic evidence that aphids rather than plants, determine gall morphology. Proc. R. Soc. London, Series B, 266: 85-89.

TAKVORIAN P.M., CALI A. 1983: Appendages associated with Glugea stephani, a microsporidian found in flounder. J. Protozool. 30: 251-256.

TAKVORIAN P.M., CALI A. 1986: The ultrastructure of spores (Protozoa: Microsporida) from Lophius americanus, the anglerfish. J. Protozool. 33: 570-575.

UNDEEN A.H. 1990: A proposed mechanism for the germination of microsporidian (Protozoa: Microspora) spores. J. Theor. Biol. 142: 223-235.

VÁVRA J. 1962: Bacillidium cyclopis n. sp. (Cnidospora, Microsporidia), a new parasite of copepods. Věstn. Česk. Spol. Zool. 26: 295-299.

WEIDNER E. 1976: Ultrastructure of the peripheral zone of a Glugea-induced xenoma. J. Protozool. 23: 234-238.

WEISER J. 1966: [Insect diseases.] Academia, Prague, 554 pp. (In Czech.)

WEISSENBERG R. 1922: Mikrosporidien und Chlamydozoen als Zellparasiten von Fischen. Verh. Dtsch. Zool. Ges. 27: 41-43.

WEISSENBERG R. 1926: Microsporidien aus TipulidenLarven. Arch. Protistenkd. 54: 431-467.

WEISSENBERG R. 1949: Cell growth and cell transformation induced by intracellular parasites. Anat. Rec. 103: 517-518.

WEISSENBERG R. 1968: Intracellular development of the microsporidian Glugea anomala Moniez in hypertrophying migratory cells of the fish Gasterosteus aculeatus L., an example of the formation of "xenoma tumours". J. Protozool. 15: 44-57.

WURMBACH H. 1935: Über die Beeinflussung des Wirtsgewebes durch Aggregata octopiana und Klossia helicina. Arch. Protistenkd. 84: 257-284. 